\title{
The influence of age and crown position on growth efficiency along a Scots pine chronosequence
}

\author{
Mieczysław Turski, \\ Hanna Kwaśna, \\ Cezary Beker, \\ Roman Jaszczak, \\ Katarzyna Kaźmierczak, \\ Tomasz Najgrakowski, \\ Wojciech Borzyszkowski
}

\begin{abstract}
The study deals with the effects of age and crown position (either dominant or intermediate, as determined by Kraft's social class) on stemwood growth efficiency (GE), which is viewed as the ratio of annual stemwood volume increment of the previous five years to needle volume of the entire tree, in eight even-aged pure stands of Scots pine (Pinus sylvestris L.). The highest GE was observed in the youngest stands, and the lowest in the oldest ones. There was no clear interdependence of $G E$ on the age of intermediate stands. $G E$ was most variable in the youngest, the 25 -year-old stand, and was the least variable in the 74-year-old stand. GE in dominant trees was lower in 25- 74- and 85-year-old stands and higher in 33-, 44-, 56-, 64- and 93-year-old stands. The GE ratios of dominant trees to intermediate trees in 25-, 33-, 44-, 56-, 64-, 74-, 85- and 93-year-old stands were 0.47:1, 1:0.93, 1:0.87, 1:0.81, 1:0.86, $0.88: 1,0.90: 1$ and 1:0.61, respectively. Tree age had a statistically significant effect on GE; however, the contribution of the age factor to GE was assessed as weak. Generally, the position of trees (whether dominant or intermediate) had no effect on GE, while age $\times$ position of trees had a statistically significant effect on $G E$, which means that the two factors interacted. The correlation between GE and tree height, diameter at breast height (DBH), and the needle volume of the entire empirical material was statistically significant with a negative sign; however, the situation varied among the particular stands.
\end{abstract}

Keywords: Pine, Needle Volume, Growth Efficiency, Dominant Trees, Intermediate Trees

thesis (Monteith 1972). The production of wood depends on the absorption of light, and the efficiency with which it is used. Larger trees absorb more light and use it more efficiently (Binkley et al. 2013). Their greater growth results from a combination of increased light absorption and increased efficiency.

The GE index may be determined in various ways depending on the available volume increments and the measured elements of the crown. Dengler (1937) defined it as the ratio of increment in stem volume to dry needle mass. Schmidt (1953) defined it as the mass of annual increment in the absolute dry matter of wood per unit of dry needle mass. Mayer (1958) introduced the concept of assimilation intensity or assimilation energy, defined on the basis be to be most closely related to wood production, as it is the main driver for photosyn- of annual increment in tree volume per unit area of crown projection or crown mantle. A similar approach was adopted by Borowski (1966). Lemke (1968) proposed determining the GE in Scots pine (Pinus sylvestis L.) as the ratio of increment in stem volume to volume of leafy twigs. Waring et al. (1980) calculated GE from the ratio of stemwood volume increment $\left(v_{\mathrm{i}}, \mathrm{dm}^{3}\right)$ to projected leaf area. The index proposed by Waring et al. (1980) is the one most commonly used nowadays.

There are three relationship patterns between growth efficiency (GE) and projected leaf area (LA): monotonic increasing, peaking, or monotonic decreasing. All of them arise from a strong relationship between the increment of stemwood volume and the area of projected leaves. The graphs display concave, sigmoid or convex shapes (Seymour \& Kenefic 2002). Interestingly, the monotonically decreasing GE pattern appears to gather strong empirical support (Roberts et al. 1993, Gilmore \& Seymour 1996, Maguire et al. 1998).

The variation in GE is relatively well scrutinized among the even-aged stands of a single species. However, it is less evident in cases of varied structural characteristics, i.e., a history of past suppression (Maguire et al. 1998) or specific forest management (Vose \& Allen 1988, Velazquez-Martinez et al. 1992), site quality, stand structure, canopy strata, age and tree size or crown 
class (O'Hara 1988, 1996, Long \& Smith 1990, Roberts \& Long 1992, Gilmore \& Seymour 1996, Sterba \& Amateis 1998, Seymour \& Kenefic 2002, Burkes et al. 2003, Reid et al. 2004, Berrill \& O'Hara 2007), as well as shade tolerance (Roberts et al. 1993, Gersonde \& O'Hara 2005).

The aim of this study was to investigate the effects of age and different positions of the crown (dominant or intermediate, as determined by Kraft's social class) on growth efficiency in eight even-aged and pure stands of Scots pine ( $P$. sylvestis) which grew in one location in western Poland. The study evaluates differences in productivity potential in the naturally variable $P$. sylvestris chronosequence.

Owing to concerns expressed by Waring et al. (1980) about their own GE index, which proved to be inconsistent with suppressed trees and may be sensitive to environment and the influence of competition, $G E$ in this study was calculated following the model of Lemke (1968) with modification introduced by the authors. The GE used in the study is viewed as a ratio of annual increment in stemwood volume of the last five years to volume of twigs with needles which come from the entire tree. A similar approach has recently been proposed by Burkes et al. (2003), who calculated growth efficiency as an annual increment in stemwood volume to needle biomass. Therefore, the following two hypotheses were considered: (i) both tree age and biosocial position are factors which influence growth efficiency; and what is more (ii) growth efficiency depends on the size of the tree (breast height and height) and the volume of needles.

\section{Material and methods}

The empirical material was comprised of measurements taken from 200 sample trees, which were selected from among eight Scots pine stands, according to the Draudt scheme.

\section{Study site}

The sampling process was carried out in eight pure stands of the Scots pine ( $P$. sylvestis) growing in a fresh mixed forest, close to Murowana Goslina $\left(52^{\circ} 34^{\prime} \mathrm{N}, 17^{\circ}\right.$ $00^{\prime} \mathrm{E}$ ) in western Poland. The stands were even-aged (25-, 33-, 44-, 56-, 64- 74-, 85- and 93-years-old) and were characterized by irregular canopies. In each stand one plot with 200-350 trees was chosen. The reasoning behind choosing the particular plot locations in each stand was in order to minimize the non-age-related differences between the trees. All plots created a trajectory of changes resulting from the chronosequence. The volume-based stand density was $0.81-1.23$ and the number of trees per hectare was 402-2927 (Tab. 1). The average temperature in the five years prior to the study was $8.02{ }^{\circ} \mathrm{C}$, with average annual rainfall at $544.2 \mathrm{~mm}$.

\section{Sample tree selection}

All trees in each plot were numbered. The height $(h, m)$ and diameter at breast height $\left(d_{1.3}, \mathrm{~cm}\right)$ of each of the standing trees was determined. The mean stand height $(H, m)$ was calculated following Lorey's model. The mean diameter at breast height $\left(D_{g}\right.$, $\mathrm{cm}$ ) of the stand was calculated as DBH of the tree with mean basal area. In each plot, 25 sample trees (200 in total, from all of the eight stands) were selected according to the Draudt method.

\section{Measurements on the sample trees}

The social position of each tree within the stand was assessed according to Kraft's classification. The sample trees were felled and divided into one-meter-long sections. Stemwood discs which were $5-\mathrm{cm}$ thick were cut at the heights of $0.0,0.5,1.3$ (breast height), 1.5, $2.5 \mathrm{~m}$, and upwards to the top. All twigs with needles were trimmed from the crown of each tree, and their mass $(M, \mathrm{~kg})$ was determined immediately afterwards. The samples of fresh twigs with needles were collected for laboratory analyses; $20 \%$ of twigs were collected for laboratory analyses from the trees aged between 25 and 56 years, whereas in the group aged $64-93$ years only $10 \%$ of twigs were collected. The sample mass of twigs with needles $\left(M_{s}, \mathrm{~kg}\right)$ was not lower than $2 \mathrm{~kg}$ and its weight depended on the stand's age.

\section{Laboratory procedure}

Stemwood discs were used to estimate the stemwood volume and to calculate the mean annual stemwood volume increment in the previous five years $\left(i_{v}, \mathrm{~m}^{3}\right)$. The twig samples with needles were used to estimate the volume of needles from one tree $\left(v_{i}, m^{3}\right)$. Next, the needles were separated from the twigs and then the total volume of needles in each sample was measured by means of xylometry, and this was used to determine the volume of needles of the entire tree $\left(v_{n}, m^{3}\right)$ according to the formula (eqn. 1):

$$
v_{n}=\frac{v_{i} \cdot M}{M_{s}}
$$

GE was estimated from the ratio of annual stemwood volume increment in the previous five years $\left(i_{v_{1}}\right)$ to needle volume of the entire tree $\left(v_{n}\right)$. GE indicates the volume of stemwood produced within one year per needle volume of the entire tree.

\section{Statistical analysis}

The GE of each of 200 sampled trees allowed the calculation of the arithmetic means and coefficients of variation (CV) for each of the eight examined stands. Both measures were calculated for dominant (Kraft's classes 1, 2, 3) and intermediate trees (Kraft's classes 4, 5). The assumptions of normality and the equal variance of GE were assessed using the Shapiro-Wilk test in order to adopt the appropriate tests and procedures necessary for further analysis. The relationship between $G E$ and height $(h)$, diameter at breast height $(d)$, and needle volume of the trees $\left(v_{n}\right)$ in each stand was assessed using the Pearson's correlation coefficient. The differences in GE between the eight stands and the contribution of the independent variables (age, dominant or intermediate trees, age $x$ dominant or intermediate trees) to GE

Tab. 1 - Structural characteristics of stands and sample trees. $\left(D_{g}\right)$ : mean diameter at breast height; $(H)$ : mean stand height; $\left(d_{1.3}\right)$ : diameter at breast height; $(h)$ : tree height; $\left(v_{n}\right)$ : needle volume of the whole tree; $\left(i_{v 1}\right)$ : mean annual stemwood volume increment in the previous 5 years; (CV): coefficient of variation.

\begin{tabular}{|c|c|c|c|c|c|c|c|c|c|c|c|c|c|c|}
\hline \multicolumn{5}{|l|}{ Stand } & \multicolumn{10}{|c|}{ Sample trees } \\
\hline \multirow{2}{*}{$\begin{array}{l}\text { Age } \\
\text { (yrs) }\end{array}$} & \multirow[b]{2}{*}{ Density } & \multirow{2}{*}{$\begin{array}{l}\text { Trees } \\
\text { ha }^{-1}\end{array}$} & \multirow{2}{*}{$\begin{array}{c}D_{\mathrm{g}} \\
(\mathrm{cm})\end{array}$} & \multirow{2}{*}{$\begin{array}{c}H \\
(\mathrm{~m})\end{array}$} & \multicolumn{2}{|c|}{$d_{1.3}(\mathrm{~cm})$} & \multicolumn{2}{|c|}{$h(\mathrm{~m})$} & \multicolumn{2}{|c|}{$v_{n}\left(m^{3}\right)$} & \multicolumn{2}{|c|}{$i_{\mathrm{v} 1}\left(\mathrm{~m}^{3}\right)$} & \multicolumn{2}{|c|}{ Number of sample trees } \\
\hline & & & & & Mean & $\begin{array}{l}\mathrm{CV} \\
(\%)\end{array}$ & Mean & $\begin{array}{l}\text { CV } \\
(\%)\end{array}$ & Mean & $\begin{array}{l}\text { CV } \\
\text { (\%) }\end{array}$ & Mean & $\begin{array}{l}\mathrm{CV} \\
(\%)\end{array}$ & $\begin{array}{c}\text { Dominant } \\
\text { trees }\end{array}$ & $\begin{array}{c}\text { Intermediate } \\
\text { trees }\end{array}$ \\
\hline 25 & 1.17 & 2590 & 13.4 & 15.49 & 12.9 & 24.4 & 13.4 & 9 & 0.0094 & 100.1 & 0.0067 & 71.8 & 19 & 6 \\
\hline 33 & 1.2 & 2927 & 13.7 & 16 & 12.2 & 29.5 & 14.6 & 7.9 & 0.0082 & 77.5 & 0.0055 & 83.3 & 17 & 8 \\
\hline 44 & 1.23 & 1225 & 20.4 & 21.23 & 19 & 22.4 & 20.4 & 7.1 & 0.0151 & 69.8 & 0.0138 & 64.1 & 18 & 7 \\
\hline 56 & 1.1 & 1160 & 20 & 21.65 & 17.8 & 25.7 & 20 & 8.9 & 0.0139 & 73.7 & 0.0119 & 73 & 17 & 8 \\
\hline 64 & 0.94 & 766 & 23.7 & 24.74 & 21.9 & 21.7 & 23.2 & 8 & 0.0204 & 62 & 0.0155 & 66.9 & 17 & 8 \\
\hline 74 & 0.81 & 537 & 25.5 & 24.46 & 24.8 & 21.3 & 23.4 & 7 & 0.0197 & 64.2 & 0.0156 & 57.2 & 19 & 6 \\
\hline 85 & 0.88 & 419 & 30.8 & 28.32 & 30.2 & 17.9 & 26.8 & 6.3 & 0.0293 & 54.9 & 0.0234 & 51.3 & 20 & 5 \\
\hline 93 & 0.91 & 402 & 31.4 & 26.12 & 29.4 & 17.6 & 25.6 & 5.9 & 0.0334 & 53.5 & 0.0162 & 59.2 & 19 & 6 \\
\hline
\end{tabular}


Tab. 2 - Growth efficiency (GE) of all sample trees and of dominant and intermediate trees.

\begin{tabular}{|c|c|c|c|c|c|c|c|c|c|}
\hline \multirow{2}{*}{$\begin{array}{c}\text { Age of } \\
\text { stand (yrs) }\end{array}$} & \multicolumn{4}{|c|}{ All sample trees } & \multicolumn{2}{|c|}{ Dominant trees } & \multicolumn{2}{|c|}{ Intermediate trees } & \multirow{2}{*}{$\begin{array}{l}\text { Contribution of } \\
\text { dominant trees (\%) }\end{array}$} \\
\hline & Mean & Min & $\operatorname{Max}$ & CV (\%) & Mean & CV (\%) & Mean & CV (\%) & \\
\hline 25 & 0.9515 & 0.4854 & 2.6286 & 57.6 & 0.7493 & 27.8 & 1.5919 & 50.1 & -53 \\
\hline 33 & 0.6713 & 0.4912 & 0.888 & 19 & 0.6867 & 16.5 & 0.6386 & 24.8 & +7.5 \\
\hline 44 & 0.9116 & 0.3292 & 1.3099 & 24.1 & 0.9444 & 18.4 & 0.8271 & 37.5 & +14 \\
\hline 56 & 0.8478 & 0.4883 & 1.2347 & 21.2 & 0.9028 & 18.6 & 0.7308 & 21 & +23.5 \\
\hline 64 & 0.7299 & 0.4432 & 0.952 & 17.9 & 0.7628 & 14.6 & 0.6599 & 22.6 & +15.5 \\
\hline 74 & 0.8317 & 0.5473 & 1.06 & 17.1 & 0.8047 & 18.3 & 0.9174 & 9.4 & -12 \\
\hline 85 & 0.8377 & 0.3508 & 1.3421 & 29 & 0.8193 & 31.1 & 0.9113 & 20.9 & -10 \\
\hline 93 & 0.4789 & 0.2086 & 0.8701 & 33.7 & 0.5279 & 27.8 & 0.3239 & 29.5 & +63 \\
\hline
\end{tabular}

were analyzed using a two-way ANOVA. The significance of the difference between $G E$ in the eight stands was calculated using the non-parametric Kruskal-Wallis test. The computed probability level for this test was $<0.0001$. The extent of the influence of age and position on growth efficiency was analyzed with coefficients $\eta^{2}$ and $\omega^{2}$ (Stanisz 2007). $\eta^{2}$ is the proportion of variance associated with one or more main effects, errors or interactions in ANOVA, while $\omega^{2}$ is a measure of effect size, or the degree of association for a population.

\section{Results}

The structural characteristics of each stand (density, number of trees per hectare, average diameter at breast height and mean stand height) and of the sample trees are presented in Tab. 1. In the sample trees: (i) diameter at breast height $\left(d_{1.3}\right)$ and the tree height $(h)$ were smallest in, respectively, the 33- and 25-year-old stands $(12.2 \mathrm{~cm}$ and $13.4 \mathrm{~m})$ and they increased with age $\left(30.2 \mathrm{~cm}\right.$ and $26.8 \mathrm{~m}$ in the $85^{-}$ year-old stand); (ii) needle volume $\left(v_{n}\right)$ and annual stemwood volume increment $\left(i_{v_{1}}\right)$ were lowest in the 33-year-old stand (0.0082 $\mathrm{m}^{3}$ and $0.0055 \mathrm{~m}^{3}$, respectively) and highest in the 85- and 93-year-old stands $\left(0.0293 \mathrm{~m}^{3}\right.$ and $0.0334 \mathrm{~m}^{3}$, and $0.0162 \mathrm{~m}^{3}$ and $0.0234 \mathrm{~m}^{3}$ ); (iii) trees with a dominant crown position accounted for $68 \%$ in the 33-, 56- and 64-year-old stands and up to $80 \%$ in the 85 -year-old stand. The smallest variation was observed in the tree diameter at breast height (17.6-29.5\%) and the tree height (5.9-9.0\%). A much greater variation occurred in the needle volume (53.5-100.1\%) and the annual stemwood volume increment (51.3-83.3\%). The variability of the individual characteristics was most noticeable in the two youngest stands, and smallest in the two oldest stands.

In the sample trees, GE was: (i) highest in the youngest, 25-year-old stand (0.9515) and smallest in the oldest, 93-year-old stand (0.4789 - Tab. 2); (ii) similar in the 56-, 74- and 85-year-old stands (0.83170.8478 ); (iii) variable between $33-$ and 85 year-old-stands; (iv) most variable (5.4-fold, $\mathrm{CV}=57.6 \%$ ) and least variable (1.8-fold, $\mathrm{CV}=$ $17.1 \%$ ) in, respectively, the 25 - and 74 -yearold stands; ( $v$ ) higher in dominant trees than in the intermediate trees of the 33-,

Tab. 3 - Results of ANOVA tests for the effect of age and position on growth efficiency (GE). (df): degrees of freedom.

\begin{tabular}{lrrrrr}
\hline Effect & \multicolumn{1}{c}{ SS } & \multicolumn{1}{c}{ df } & \multicolumn{1}{c}{ MS } & \multicolumn{1}{c}{$\boldsymbol{F}$} & \multicolumn{1}{c}{$\boldsymbol{p}$} \\
\hline Intercept & 98.81039 & 1 & 98.81039 & 2103.699 & $<0.0001$ \\
\hline Age & 5.92625 & 7 & 0.84661 & 18.024 & $<0.0001$ \\
\hline Dominant and intermediate trees & 0.09795 & 1 & 0.09795 & 2.085 & 0.1504 \\
\hline Age $\times$ dominant and intermediate trees & 3.76578 & 7 & 0.53797 & 11.453 & $<0.0001$ \\
\hline Error & 8.64245 & 184 & 0.04697 & & \\
\hline
\end{tabular}

Tab. 4 - Contribution of age and position to growth efficiency (GE, \%).

\begin{tabular}{lrr}
\hline Independent variable & \multicolumn{1}{c}{$\eta^{2}$} & $\omega^{2}$ \\
\hline Age & 40.68 & 30.29 \\
Dominant and intermediate trees & 1.12 & 0.28 \\
\hline Age $\times$ dominant and intermediate trees & 30.35 & 18.60 \\
\hline
\end{tabular}

44-, 56-, 64- and 93-year-old stands (from 7.5 to $63 \%$ ); (vi) lower in the dominant trees than in the intermediate trees of the 25-, 74- and 85-year-old stands (over twofold in the youngest stand). In the dominant trees, GE varied most in the 85-year-old stand $(C V=31.1 \%)$ and least in the 64-yearold stand $(C V=14.6 \%)$. In intermediate trees, $G E$ was most variable in the 25 -yearold stand $(C V=50.1 \%)$.

The age of trees had a statistically significant effect on $G E\left(F_{\text {Age }}=M S_{\text {Age }} / M S_{\text {Error }}=\right.$ 18.024 (Tab. 3). The contribution of age to

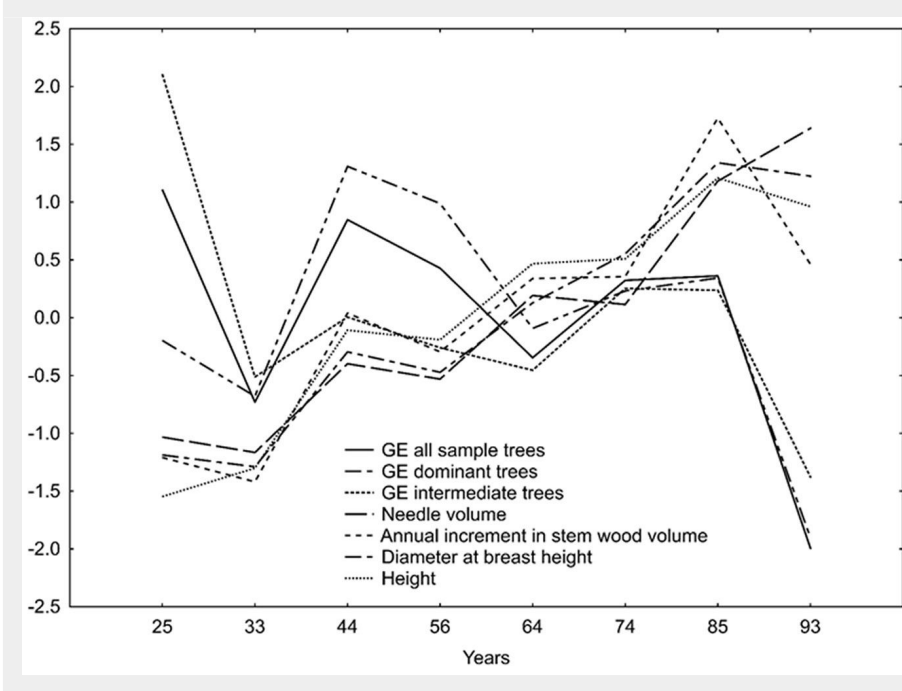

GE was $40.68 \%$ (see $\eta_{\text {Age in Tab. 4). The sum }}^{2}$ of the partial variance $\omega^{2}$ was $49.17 \%$.

In comparison to the intermediate trees, GE in the dominant trees was lower in 2574- and 85 -old stands (10-53\%) and greater in 33- 44-, 56- 64- and 93-old-stands (7.5$63 \%$ - Tab. 2). The ratios of the GE of dominant trees to the GE of intermediate trees in 25-, 33-, 44-, 56-,64-, 74-, 85- and 93-yearold stands were $0.47: 1,1: 0.93,1: 0.87,1: 0.81$, 1:0.86, $0.88: 1,0.90: 1$, and 1:0.61. Generally, however, the position of trees (whether dominant or intermediate) had no signifi-
Fig. 1 - Growth efficiency (GE) in sample trees in association with mean height, mean diameter at breast height, annual stemwood volume increment and needle volume (standardized values - Statistica ver. 13.1, Tulsa, OK, USA). 
Tab. 5 - Pearson's correlation coefficients between growth efficiency (GE) and diameter at breast height $\left(d_{1.3}\right)$, tree height $(h)$ and needle volume $\left(v_{n}\right) .(*): p<0.05$.

\begin{tabular}{cccc}
\hline Age of stand (years) & $\boldsymbol{d}_{1.3}$ & $\boldsymbol{h}$ & $\boldsymbol{V}_{\mathbf{n}}$ \\
\hline 25 & $-0.528^{*}$ & $-0.505^{*}$ & $-0.460^{*}$ \\
\hline 33 & 0.180 & 0.234 & -0.023 \\
\hline 44 & 0.283 & $0.526^{*}$ & 0.014 \\
\hline 56 & 0.350 & 0.388 & 0.064 \\
\hline 64 & $0.451^{*}$ & $0.477^{*}$ & $0.401^{*}$ \\
\hline 74 & -0.295 & -0.166 & $-0.484^{*}$ \\
85 & -0.131 & 0.005 & -0.321 \\
\hline 93 & $0.430^{*}$ & $0.548^{*}$ & 0.095 \\
\hline $25-93$ (all sample trees) & $-0.144^{*}$ & $-0.155^{*}$ & $-0.195^{*}$ \\
\hline
\end{tabular}

Tab. 6 - Assessment of normality of distribution of growth efficiency using the Shapiro-Wilk test.

\begin{tabular}{|c|c|c|c|c|c|c|c|c|}
\hline \multirow{2}{*}{$\begin{array}{l}\text { Shapiro-Wilk } \\
\text { test }\end{array}$} & \multicolumn{8}{|c|}{ Stand (years) } \\
\hline & 25 & 33 & 44 & 56 & 64 & 74 & 85 & 93 \\
\hline$w$ & 0.70328 & 0.92582 & 0.97733 & 0.95761 & 0.96254 & 0.96259 & 0.97887 & 0.95334 \\
\hline$p$-value & 0.00001 & 0.06964 & 0.82769 & 0.36887 & 0.46727 & 0.46838 & 0.86172 & 0.29774 \\
\hline
\end{tabular}

cant effect on GE ( $p=0.1504, \eta^{2}$ Dominant and intermediate trees $=1.12-$ Tab. 3, Tab. 4).

Age $\times$ position of trees had a statistically significant effect on $G E$, which means that the two factors interacted $\left(\eta^{2}\right.$ Age $\times$ dominant and in termediate trees $=30.35-$ Tab. 4). The contribution of other factors (including any that were not part of this study) was $50.83 \%$ (Tab. 4).

GE was negatively correlated with tree height, diameter at breast height, and needle volume at the ages of 25 and 74 (partly), and positively correlated at the ages of 44, 64, and 93 years (partly - Tab. 5). A long-lasting GE decline was, however, associated with the independent, possibly confounding, effects of a moderate but continuous increase in mean tree height, mean diameter at breast height, annual stemwood volume increment, and needle volume (Fig. 1).

The Shapiro-Wilk test indicated that the GE of 25-year-old trees was not normally distributed. Thus, the non-parametric Krus-
kal-Walis test was used to compare the mean GE of the sample trees from the eight stands. The results showed that the GE of trees was not significantly different among the majority of stands. Multiple comparison analyses showed that the GE of trees in the 93-year-old stand differs significantly from all the others, except the 33-year-old one. Another significant difference occurs between 33- and 44-year-old trees; the differences in GE among trees of other ages were statistically insignificant (Tab. 6, Tab. 7).

\section{Discussion}

The growth of individual forest trees declines with age and, furthermore, the decline stems from their reduced resourceuse efficiency (Ryan et al. 1997).

We observed that the GE of a P. sylvestris forest in even-aged plantations varied with age. Generally, in the long term, between the ages $25-93$, there was a slow but continuous decline, with temporary fluctua- tions observed as the stand was aging. The highest GE value was observed relatively early, in the 25-year-olds. This was followed by a substantial aberration between 30and 85 -year-olds and a sudden decline afterwards ( $G E=0.4789$ at 93 years). The high GE in the youngest plantation resulted largely from the contribution of the intermediate trees.

Such or similar age-related GE patterns have also occurred in other coniferous and deciduous forests (Long \& Smith 1990, Gower et al. 1996, Kira \& Shidei 1967, Ryan et al. 1997, 2004). P. sylvestris is the most widely distributed pine species in the world, found in many, ecologically diverse habitats, and has become very important commercially, socially and culturally. Only recently its growth has been studied by numerous authors (Vanninen \& Mäkelä 2000 , Martínez-Vilalta et al. 2007, Riofrío et al. 2016).

Although the growth efficiency was calculated as a ratio of annual increment in the stemwood volume to the volume of needles, and not to the projected leaf area as proposed by Seymour \& Kenefic (2002), we still observed the monotonically decreasing pattern, which is the most common one. In Poland similar monotonically decreasing patterns of $G E$ in $P$. sylvestris were earlier observed by Lemke (1974). A similar pattern among Abies balsamea (L.) Mill., Picea rubens Sarg., Pinus contorta Dougl. ex Loud, and Pinus strobus L. was observed in Europe and the USA by Roberts et al. (1993), Maguire et al. (1998), and DeRose \& Seymour (2009).

We also analyzed fluctuations in GE in dominant $v s$. intermediate trees and the results were connected with age. A higher GE of dominant trees was observed in most stands and ages; however, it declined with age. The ratio of the GE of dominant trees to the GE of intermediate trees was only partly in agreement with Lemke's estimates (Lemke 1968), who observed that in a 35-year-old stand of $P$. sylvestris the ratios of the GE of class 1 trees to the GE of class 2, 3, 4 and 5 trees were 1:1.18, 1:1.13, 1:0.94 and 1:0.67, and in a 50-year-old stand the

Tab. 7 - Significance of differences in growth efficiency (GE) among the eight studied stands. Multiple comparisons $p$-values (Kruskal-Wallis test, 2-tailed) are shown. Independent (grouping) variable: Age (years); Kruskal-Wallis $\mathrm{H}_{[7,200]}=63.82966, p<0.0001$. $(\mathrm{R})$ : mean rank value.

\begin{tabular}{ccccccccc}
\hline \multirow{2}{*}{$\begin{array}{c}\text { Stand Age } \\
\text { (years) }\end{array}$} & \multicolumn{7}{c}{ Stand Age (years) } \\
\cline { 2 - 9 } & $\mathbf{2 5}$ & $\mathbf{3 3}$ & $\mathbf{4 4}$ & $\mathbf{5 6}$ & $\mathbf{6 4}$ & $\mathbf{7 4}$ & $\mathbf{8 5}$ & $\mathbf{9 3}$ \\
\hline 25 & - & 0.683929 & 1.000000 & 1.000000 & 1.000000 & 1.000000 & 1.000000 & 0.000049 \\
\hline 33 & 0.683929 & - & 0.001504 & 0.062156 & 1.000000 & 0.053180 & 0.124702 & 0.320371 \\
\hline 44 & 1.000000 & 0.001504 & - & 1.000000 & 0.125662 & 1.000000 & 1.000000 & $<0.000001$ \\
\hline 56 & 1.000000 & 0.062156 & 1.000000 & - & 1.000000 & 1.000000 & 1.000000 & 0.000001 \\
\hline 64 & 1.000000 & 1.000000 & 0.125662 & 1.000000 & - & 1.000000 & 1.000000 & 0.005444 \\
\hline 74 & 1.000000 & 0.053180 & 1.000000 & 1.000000 & 1.000000 & - & 1.000000 & $<0.000001$ \\
\hline 85 & 1.000000 & 0.124702 & 1.000000 & 1.000000 & 1.000000 & 1.000000 & - & 0.000002 \\
\hline 93 & 0.000049 & 0.320371 & $<0.000001$ & 0.000001 & 0.005444 & $<0.000001$ & 0.000002 & - \\
\hline
\end{tabular}


ratios were 1:1.10, 1:1.02, 1:0.77 (with no class 5).

The fluctuations in age-related GE agree with the hypothesis put forward by Binkley (2004), who observed regular and continuous changes in contribution of dominant and non-dominant trees to productivity of forest. In younger stands, prior to canopy closure, the dominance is usually low, and resource-use efficiency for all trees is high. In older stands near canopy closure, however, the increasing dominance reduced resource-use efficiency by non-dominant trees, which decreased forest productivity. Furthermore, in older stands the resourceuse efficiency continuously declined in the largest trees and reduced the level of dominance. The growth dominance pattern has been observed in stands of native forest co-dominated by Pseudotsuga menziesii Carriere, Tsuga heterophylla (Raf.) Sarg. and Picea sitchensis (Bong.) Carr. (Binkley 2004), Pinus elliottii Engelm. and Pinus taeda L. (Martin \& Jokela 2004), and Pinus resinosa Sol. ex Aiton (Bradford et al. 2010). An increasing GE in trees with more dominant crown classes of the same species has been observed by Waring et al. (1980), O'Hara (1988), and Sterba (2005). However, Reid et al. (2004) found an opposed pattern. The differences resulted from stand structure, ecological conditions, species-specific effects, methods used to evaluate tree increment and crown projection area, and variations in assimilation efficiency. The history of past suppression, planting density, canopy/strata class, age, size, availability of light, and tolerance to shade have significant effects on the crown leaf area, contributing to growth efficiency (Assmann 1961, Schulze et al. 1977, Chen et al. 1996, O'Hara 1996, 1988, Maguire et al. 1998, Sterba \& Amateis 1998, Seymour \& Kenefic 2002, Burkes et al. 2003, Reid et al. 2004, Gersonde \& O'Hara 2005). It is vital to observe that (i) greater past suppression diminished growth efficiency in Picea rubens; (ii) shade significantly decreased (50\%) growth efficiency in intermediate trees of Betula and Picea, compared to dominant trees growing under advantageous light conditions; (iii) low density of planting decreased growth efficiency in Pinus taeda and Pinus elliottii .

This study was conducted on sites which were considered as having a high productivity potential. A better site quality usually positively influences GE. The effect may, however, be species-specific; GE increased significantly in shade-intolerant Abies balsamea, moderately in shade-tolerant Abies lasiocarpa (Hook.) Nutt. and Picea engelmannii Parry ex Engelm., and was stable in shade-tolerant Picea rubens and shade-intolerant Pinus contorta (Meng \& Seymour 1992, Reid et al. 2004, Seymour \& Kenefic 2002). It is possible that the GE response depends on site quality. However, the reaction depends also on the species. DeRose \& Seymour (2009) observed that a higher site index caused an increase in growth ef- ficiency in Abies balsamea, but not in Picea rubens.

\section{Conclusion}

The long-term productivity of $P$. sylvestris forest declines with age. The greatest mean growth efficiency in the Scots pine was found in the youngest trees, while it was lowest for the oldest trees. This may result from the fact that the analyses did not include increment in the biomass of branches or roots, increasing with age.

The mean growth efficiency of the youngest intermediate trees was over 2-fold greater than for the dominant trees. An opposite situation was found in the oldest trees, in which mean growth efficiency for dominant trees was over 1.6-fold greater than for intermediate trees.

The greatest variation in growth efficiency was observed for the youngest trees. Regarding tree social position, variation in the growth efficiency of intermediate trees is greater than that of dominant trees in six out of eight analyzed stands.

Only in the youngest stand and in the 64year-old stand we found a significant dependence of growth efficiency (GE) on diameter at breast height $\left(d_{1.3}\right)$, tree height $(h)$, and needle volume $\left(v_{n}\right)$ observed. An increase in each of the three traits in the case of the youngest trees resulted in a reduction of growth efficiency, while for 64year-old trees it led to its increase. The two-way analysis of variance indicated a significant effect of the tree age on growth efficiency. However, the affiliation of trees to the group either as dominant or intermediate trees caused no such effect.

According to the arbitrary scale of effects of the analysis of variance given by Cohen (1988), the effect of the age on the growth efficiency needs to be considered as weak (30.29\%), that of the social class of tree position (dominant vs. intermediate trees) very small $(0.28 \%)$, while that of the interaction of factors dominant or intermediate trees as small (18.60\%).

\section{Acknowledgements}

This works was co-financed within the framework of Ministry of Science and Higher Education programme as "Regional Initiative Excellence" in years 2019-2022, project number 005/RID/2018/19.

\section{References}

Assmann E (1961). Waldertragskunde. [Forest Yield Science]. BLV-Verlagsgesellschaft, München-Bonn-Wien, pp. 490. [in German]

Berrill JP, O'Hara KL (2007). Patterns of leaf area and growing space efficiency in young even aged and multiaged coast redwood stands. Canadian Journal of Forest Research 37 (3): 617-626. - doi: 10.1139/X06-271

Binkley D (2004). A hypothesis about the interaction of tree dominance and stand production through stand development. Forest Ecology and Management 190: 265-271. - doi: 10.1016/j. foreco.2003.10.018

Binkley D, Laclau JP, Sterba H (2013). Why one tree grows faster than another: patterns of light use and light use efficiency at the scale of individual trees and stands. Forest Ecology and Management 288: 1-4. - doi: 10.1016/j.foreco.201 2.08.009

Borowski M (1966). Uber den Zuwachs der sozialen Baumklassen in Kiefernbeständen. [About the growth of social tree classes in pine stands]. Archiv für Forstwesen 3: 233-241. [in German]

Bradford JB, D'Amato AW, Palik BJ, Fraver S (2010). A new method for evaluating forest thinning: growth dominance in managed Pinus resinosa stands. Canadian Journal of Forest Research 40 (5): 843-849. - doi: 10.1139/X10-039 Burkes EC, Will RE, Barron Gafford GA, Teskey RO, Shiver B (2003). Biomass partitioning and growth efficiency of intensively managed Pinus taeda and Pinus elliottii stands of different planting densities. Forest Science 49 (2): 224234. [online] URL: http://academic.oup.com/for estscience/article/49/2/224/4617479/

Chen HYH, Klinka K, Kayahara GJ (1996). Effect of light on growth, crown architecture, and specific leaf area for naturally established Pinus contorta var. latifolia and Pseudotsuga menziesii var. glauca saplings. Canadian Journal of Forest Research 26 (7): 1149-1157. - doi: 10.1139/x26-128 Cohen J (1988). Statistical power analysis for behavioral sciences $\left(2^{\text {nd }}\right.$ edn). Lawrence Erlbaum Associates, Hillsdale, NJ, USA, pp. 567.

Dengler A (1937). Kronengröße, Nadelmenge und Zuwachsleistung von Altkiefern [Crown size, needle quantity and increment performance of old pines]. Zeitschrift für das Forstund Jagdwesen 69: 321-336. [in German]

DeRose RJ, Seymour RS (2009). The effect of site quality on growth efficiency of upper crown class Picea rubens and Abies balsamea in Maine, USA. Canadian Journal of Forest Research 39 (4): 777-784. - doi: 10.1139/Xo9-012

Gersonde RF, O'Hara KL (2005). Comparative tree growth efficiency in Sierra Nevada mixedconifer forests. Forest Ecology and Management 219 (1): 95-108. - doi: 10.1016/j.foreco.200 5.09 .002

Gilmore DW, Seymour RS (1996). Alternative measures of stem growth efficiency applied to Abies balsamea from four canopy positions in central Maine, USA. Forest Ecology and Management 84 (1-3): 209-218. - doi: 10.1016/0378$1127(96) 03728-0$

Gower ST, McMurtrie RE, Murty D (1996). Above ground net primary production decline with stand age: potential causes. Trees 11 (9): 378382.

Kira T, Shidei T (1967). Primary production and turnover of organic matter in different forest ecosystems of the western Pacific. Japanese Journal of Ecology 17 (2): 70-87. - doi: 10.1896 o/seitai.17.2_70

Lemke J (1968). Zwia1zek pomiedzy wielkoscia korony a przyrostem drzew w drzewostanach sosnowych [The dependence of the crown size and tree increment in the Pine stands]. Prace Komisji Nauk Rolniczych i Komisji Nauk Lesnych PTPN 25: 1-48. [in Polish]

Lemke J (1974). Wydajnosć igliwia sosny zwyczajnej w produkcji drewna strzaly. [Efficiency of Scots pine needles in stemwood production]. Sylwan 118 (9): 33-38. [in Polish] 
Long JN, Smith FW (1990). Determinants of stemwood production in Pinus contorta var. latifolia forests: the influence of site quality and stand structure. Journal of Applied Ecology 27 (3): 847-856. - doi: 10.2307/2404381

Maguire DA, Brissette JC, LianHong G (1998). Crown structure and growth efficiency of red spruce in uneven-aged, mixed-species stands in Maine. Canadian Journal of Forest Research 28: 1233-1240. - doi: 10.1139/x98-093

Martin TA, Jokela EJ (2004). Developmental patterns and nutrition impact radiation use efficiency components in southern pine stands. Ecological Applications 14 (6): 1839-1854. - doi: 10.1890/03-5262

Martínez-Vilalta J, Vanderklein D, Mencuccini M (2007). Tree height and age-related decline in growth in Scots pine (Pinus sylvestris L.). Oecologia 150 (4): 529-44. - doi: 10.1007/s00442-00 6-0552-7

Mayer R (1958). Kronengröße und Zuwachsleistung der Traubeneiche auf süddeutschen Standorten [Crown size and productivity of sessile oak on sites in southern Germany]. Allgemeine Forst- und Jagdzeitung 129 (114): 151-163. [in German]

Meng X, Seymour RS (1992). Influence of soil drainage on early development and biomass production of young, herbicide released firspruce stands in north central Maine. Canadian Journal of Forest Research 22: 955-967. - doi: 10.1139/x92-128

Monteith JL (1972). Solar radiation and productivity in tropical ecosystems. Journal of Applied Ecology 9: 747-766. - doi: 10.2307/2401901

O'Hara KL (1988). Stand structure and growing space efficiency following thinning in an even aged Douglas fir stand. Canadian Journal of Forest Research 18 (7): 859-866. - doi: 10.1139/ x88-132

O'Hara KL (1996). Dynamics and stocking-level relationships of multi-aged ponderosa pine stands. Forest Science 42 (2): 1-34. [online]
URL: http://academic.oup.com/forestscience/ article/42/suppl 2/a0001/4627269/

Reid DEB, Lieffers VJ, Silins U (2004). Growth and crown efficiency of height repressed lodgepole pine: are suppressed trees more efficient? Trees 18: 390-398. - doi: 10.1007/s00468003-0317-4

Riofrío J, Del Río M, Bravo F (2016). Mixing effects on growth efficiency in mixed pine forests. Forestry 90 (3): 381-392. - doi: 10.1093/forestry/cpw056

Roberts SD, Long JN (1992). Production efficiency of Abies lasiocarpa: influence of vertical distribution of leaf area. Canadian Journal of Forest Research 22 (9): 1230-1234. - doi: 10.1139/ x92-164

Roberts SD, Long JN, Smith FW (1993). Canopy stratification and leaf area efficiency: a conceptualization. Forest Ecology and Management 60 (1-2): 143-156. - doi: 10.1016/0378-1127(93)900 28-L

Ryan MG, Binkley D, Fownes HJ (1997). Age-related decline in forest productivity: pattern and process. Advances in Ecological Research 27: 213-262. - doi: 10.1016/Soo65-2504(08)60009-4

Ryan MG, Binkley D, Fownes HJ, Giardina CP, Senock RS (2004). An experimental test of the causes of forest growth decline with stand age. Ecological Monographs 74: 393-414. - doi: 10.18 90/03-4037

Schmidt H (1953). Kronen- und Zuwachsuntersuchungen an Fichten des bayerischen Alpenvorlandes [Crown and increment studies on spruce trees of the Bavarian Alpine foothills]. Forstwissenschaftliches Zentralblatt 72 (9-10): 276-286. [in German]

Schulze ED, Fuchs M, Fuchs MI (1977). Spatial distribution of photosynthetic capacity and performance in a mountain spruce forest of northern Germany. Oecologia 30: 239-248. doi: $10.1007 / B F 01833630$

Seymour RS, Kenefic LS (2002). Influence of age on growth efficiency of Tsuga canadensis and
Picea rubens trees in mixed-species, multi-aged northern conifer stands. Canadian Journal of Forest Research 32 (11): 2032-2042. - doi: 10.1139 |x02-120

Stanisz A (2007). Przystepny kurs statystyki z zastosowaniem STATISTICA PL na przykładach z medycyny [The intelligible statistics course using STATISTICA PL on examples from medicine]. StatSoft, Kraków, Poland, pp. 868. [in Polish]

Sterba H (2005). Gibt es eine baumindividuelle zuwachsoptimale Überschirmung - ein Beitrag zur Theorie des Einzelbaumwachstums [Is there a tree-specific growth-optimal shielding a contribution to the theory of individual tree growth]. Austrian Journal of Forest Science 2: 55-68. [in German]

Sterba H, Amateis RL (1998). Crown efficiency in a loblolly pine (Pinus taeda) spacing experiment. Canadian Journal of Forest Research 28: 1344-1351. - doi: 10.1139/x98-115

Vanninen P, Mäkelä A (2000). Needle and stem wood production in Scots pine (Pinus sylvestris) trees of different age, size and competitive status. Tree Physiology 20 (8): 527-533. - doi: 10.1093/treephys/20.8.527

Velazquez-Martinez A, Perry DA, Bell TE (1992). Response of aboveground biomass increment, growth efficiency, and foliar nutrients to thinning, fertilization, and pruning in young Douglas-fir plantations in the central Oregon Cascades. Canadian Journal of Forest Research 22: 1278-1289. - doi: 10.1139/x92-170

Vose JM, Allen HL (1988). Leaf area, stemwood growth, and nutrition relationships in loblolly pine. Forest Science 34: 546-563. [online] URL: http://academic.oup.com/forestscience/articleabstract/34/3/547/4642485/

Waring RH, Thies WG, Muscato D (1980). Stem growth per unit of leaf area: a measure of tree vigor. Forest Science 26: 112-117. [online] URL: http://academic.oup.com/forestscience/articleabstract/26/1/112/4656392/ 